brazilianpoliticalsciencereview

\title{
ARTICLE
}

\section{High-level Federal Bureaucracy and Policy Formulation: the Case of the Bolsa Família Program*}

\author{
Fabio Pereira de Andrade \\ Universidade de São Paulo, Brazil \\ Fernanda Lima-Silva \\ Fundação Getúlio Vargas-SP, Brazil
}

This article is a contribution to the study of the decisionmaking behind social policies. The literature usually stresses the role of elected politicians and the parliament in framing policies and underestimates governmental stakeholders, who do not hold elected offices, and bureaucrats. This article aims to highlight the active role of high-level federal bureaucrats in the design of policies. The analysis reclaims the classical categories and concepts developed by Lindblom (1980) and Crozier (1964), which points to the hybrid behaviour of bureaucrats and politically-appointed actors. Our aim is to show that decision-making is the result of the interactions between elected politicians and hybrid high-level federal bureaucracy, who organize themselves in groups around different technical-political projects. The analysis is developed through a case study of a policy that resulted in the merger of the existing federal conditional cash transfer programs, and generated one of the most globally-recognized social policies of Brazil, the Bolsa Família Program, in 2003.

Keywords: Bureaucracy; game of power; hybridism; Bolsa Família Program; Lula government. 
Ithough the Bolsa Família Program (PBF) has gained much attention in
social sciences, there are few studies on the process of its formulation. Some studies address the decision-making processes as related to specific issues of this program, such as conditionalities (COSTA, 2009; TREVISANI et al., 2012), social control mechanisms (SENNA et al., 2007) and targeting x universal minimum income (SILVA et al., 2007). Others analyze the role of politically-appointed agents involved in building the Social Development Ministry (Ministério do Desenvolvimento Social), who have been in charge of its implementation since 2004 (DULCI, 2010; SILVA, 2013; VIEIRA, 2011). However, studies on the dynamics of the PBF formulation process are scarce, especially on the role and influence of the different groups that are organized around technical-political projects.

Hall's analysis (2006) addresses the formulation of the PBF, but it emphasizes the resulting program's structure and the role played by the international bodies engaged therein. As a result, the domestic dynamics of national stakeholders during the decision-making process remains understudied. Therefore, there is a lack of data on the conflicts among and the influence of politicians and bureaucrats with different technicalpolitical projects in the PBF formulation.

The goal of this article is to explore the role played by visible actors, such as the president and government ministries, and invisible ones, especially the high-level bureaucracy - particularly ministry's executive secretaries - in the PBF decisionmaking. The analysis highlights the influence of the hybrid action of invisible stakeholders and consequently revisits traditional conceptions of decision-making and public policy formulation. Our main argument is that high-level bureaucrats, linked to ministries in the federal government, organized themselves around technical-political projects in order to leverage their influence on the decision-making process. Additionally, the study also argues that the organizational diversity of the Social Development Ministry (MDS) was a solution to reconcile the groups involved in the disputes around its creation.

It is important to note that PBF is the largest conditional cash transfer program in Brazilian history and one of the most important programs during the presidency of Luiz Inácio Lula da Silva, assisting 12.3 million families in 2009. It was created in 2004 
by combing other conditional cash transfer programs that existed at the time ${ }^{1}$. The program has three main axes: cash transfer, conditionalities and complementary programs. The cash transfer promotes immediate relief from the effects of poverty, giving families more chances to improve their nutrition and quality of life in general. The terms reinforce the families' access to their basic social rights in the education, health and social assistance areas, while the complementary programs focus on the families' development, with the goal of leveraging the families' capabilities and chances, thereby increasing their possibilities of overcoming their short- and long-term vulnerable condition.

This article is structured in four sections: the first revisits the theory of bureaucracy to argue in favor of bureaucrats' active role in policy decision-making. The second develops upon Lindblom's (1980) framework about the role of the competition between political-technical projects supported by stakeholders when framing policies. The third section presents the methodological strategy, while the fourth provides empirical evidences based on the case study, followed by a conclusion.

\section{The hybrid role of the bureaucracy}

The classic vision of policy design stated that bureaucrats would not have any role in decision-making. Such a vision was long-stated by Woodrow Wilson (2005), who argued that a bureaucracy should only implement policies formulated by its politicians, so bureaucracy would not take part in the decision-making process. Wilson (2005) would only allow for some limited discretionary power to choose the best tools and techniques to carry out a policy that had its main principles formulated by elected politicians.

Such a limited role for bureaucrats was reinforced by Max Weber (1993), whose work developed an ideal kind of bureaucracy (characterized by rationality, meritocracy and compliance with the norms) and highlighted other elements of bureaucratic behaviour, such as the sense of usefulness, affinity, tradition and the bureaucratic ability to implement politicians' decisions. Thus, hierarchical domination and compliance with

1 President Fernando Henrique Cardoso created the first Federal CCT, called "Eradication of Child Labor Program" (PETI), which was implemented in 1996 by the Ministry of Labor. This program transferred cash to family with school children under the condition that the children should not work. Later, this government created other programs, including Food Benefit (Bolsa Alimentação) in the Ministry of Health; School Benefit (Bolsa Escola) in the Ministry of Education; Cooking Gas Benefit (Vale Gás) in the Ministry of Mines and Energy (MME) and Income Voucher of Ministry of National Integration (MIN). 
rules framed by elected officials become a matter of professional ranking and possibility; after all, orders can be interpreted differently (OLSEN, 2005).

Philip Selznick (1943) and Michel Crozier (1964) introduced the elements of informality and the political power into the conception of the bureaucratic ideal by examining the efficacy of the ideal bureaucracy. For both authors, the bureaucracy is varied and heterogeneous. Its actions coexist with formal and informal structures, which are marked by power and personal relationships (SELZNICK, 1943). Influenced by Herbert Simon's notion of limited rationality, Crozier (1964) suggests that an analysis of the bureaucracy must encompass each individual's or groups' rationality, as well as the influence of factors that affect human relations and limit rationality.

Queries on the existence of the ideal bureaucracy were reinforced by empirical studies, which did not support the assumption of a rigid separation between political and bureaucratic stakeholders. Aberbach et al. (1981, pp. 89-94) show how a hybrid performance in the formulation of public policies gradually replaced such dichotomy, resulting in the bureaucratization of politics and politicisation of the bureaucracy ${ }^{2}$. Hence, politicians develop technical arguments similar to those of bureaucrats, to discuss the distributional effects of policies, while bureaucrats negotiate technical projects in a manner similar to politicians (Idem, 1981, pp. 89-94). In sum, both types of decisionmakers need to develop political and technical skills, although there are still differences in the performance and political role of each.

Bureaucrats and politicians act in different manners and timeframes, although both take part in the decision-making process. There are "visible" participants (such as the president, his high-level advisers, ministries, congress members, political parties, etc) and "invisible" participants (career bureaucrats, academics and civil servants working for the congress). Visible stakeholders define the agenda, whilst invisible ones have more leverage on the selection of alternatives (KINGDOM, 1995).

This study departs from these theoretical assumptions and focuses instead on the strategies adopted by ministries and the high-level federal bureaucracy of the Brazilian government when formulating the PBF. More specifically, we focus on the strategies adopted by policy-makers placed in the highest position in the Brazilian federal bureaucracy: the ministers and the executive secretaries ("Special Nature" positions, or

2 It is important to note that this study does not target regular bureaucrats, but high-level bureaucrats that take part on decision-making processes, also called "policy makers". 
NES). Also, we approach the role assumed by people in the positions of Superior Direction and Advisory (DAS) levels 05 and $06^{3}$ during the building of the Ministry of Social Development and Fight against Hunger (MDS), which became the agency responsible for PBF.

There is a debate on the role of these high-level policymakers. Some authors argue that hybridism is a reality in these positions (ABERBACH et al., 1981; LOUREIRO and ABRUCIO, 1999), while others see these positions as filled by public managers, who would have more autonomy than regular bureaucrats to define tools and the best techniques to reach the goals defined by the political core (BONIS and PACHECO, 2010). They would also be evaluated by the results achieved, defined previously in a contract. This point of view also argues that such positions are an expression of the overcoming of the dualism between political and bureaucratic roles which results in the creation of a new and specific group with their own ethos (PACHECO, 2002). However, the reality of Brazilian politics brings challenges to the full development of these managerial/direction positions, such as the free political appointment (D'ARAUJO, 2009, p. 16). In this study, we adopt the position of Loureiro and Abrucio (1999), who use the term "positions of direction in the Brazilian political-administrative system" (LOUREIRO and ABRUCIO, 1999, p. 86) and assume that direction positions are occupied by hybrid professionals, who are responsible for efficient management but also attend the political goals of the governmental agenda.

Policy-makers are usually affiliated with epistemic communities (HAAS, 1992) and policy communities (RHODES, 2006), here understood as groups who share common perspectives about policies in general which go along with specific speeches and proposals selected among policy alternatives 4 . However, Haas (1992) and Rhodes (2006) do not envisage appointed officials as performing an active role in policy framing.

Based on these concepts, we adopt the term high-level federal bureaucracy, understood as those who are politically appointed for policy-making positions in the government, more specifically the ministers and executive secretaries ${ }^{5}$. Their function

3 DAS positions levels 05 and 06 include the following: chief of staff, special advisor and subsecretaries, among others (D'ARAUJ0, 2009, p. 21).

${ }^{4}$ More specifically, the epistemic community literature recognizes the existence of the advisor, who is a hybrid stakeholder without individual interest, while the policy community literature operates with a broad concept that includes all bureaucrats and political groups.

${ }^{5}$ It is important to highlight that bureaucrats in the Superior Direction and Advisory positions levels 05 and 06 became important in more operational PBF decision-making processes after the 
demands a hybrid behaviour that combines political aims with an affiliation to specific groups involved with policy formulation.

In sum, our study is guided by the assumption that high-level bureaucrats play a relevant role in the formulation of public policies. Thus, as invisible actors, their performance is primarily directed at designing alternatives for policies included in the agenda by elected politicians. However, policy communities may be split into different groups that establish rational strategies to influence the formulation of public policies. So, unlike Haas (1992) and Rhodes (2006), we assume that invisible actors take an active role in disputes over the design of public policies.

\section{The decision-making process as a locus of power and uncertainty}

When formulating public policies, decision-makers are limited by a set of either constitutional or legal rules. At the micro level, decision-makers set their strategies based on different preferences which are informed by values, personal background, and knowledge, which can all affect the way they understand a problem and frame its solutions.

Moreover, actors involved in policy decision-making seek to increase their power (LINDBLOM, 1980). As a result, when taking part in a decision-making process, actors interact so as to influence and control each other. Lindblom (1980) named policy formulation as a "game of power", a concept that suggests a set of more complex and intimate interrelations than the terms "politics" or "interrelationship" (Idem, 1980, pp. 3940).

In the political realm, the framing of policies follows an incremental logic due to the uncertainty of the environment and the limited rationality of decision makers. Moreover, organised political groups compete against each other by making use of different tools, including money, information, organisational capacity, and persuasion. As a result, models of decision making must take account of the complexity of such political processes, particularly by paying attention to the "competition of analyses" among policymakers, be they politicians or bureaucrats (LINDBLOM, 1980).

2003 decision to unify the conditional cash transfer programs. In addition, we highlight that the interviews in this study were carried out with people who were in these positions, who reported on the PBF and MDS creation. 
This study aims at unpacking such power games by identifying different groups, their technical-political projects and the result of their interaction in formulating the PBF. Undertaking such a task is particularly complicated, as the political and technical dimensions of the dispute are usually jointly and implicitly present in actors' speeches.

\section{Methodology}

This study examines the PBF formulation process in order to better understand how policy makers interact with different projects when framing policies. The analysis is based on secondary sources, such as the minutes of inter-ministerial meetings, and interviews with ministers, executive secretaries and advisers involved in the process, as well as on semi-structured interviews with five key actors ${ }^{6}$. The method of content analysis proposed by Lopés-Aranguren (2000) was adopted to analyse interviews, so as to combine descriptive goals and inferences.

Interviewees were selected so as to represent groups with different politicaltechnical positions in charge of framing the PBF. Specifically, the analysis covers groups with opposite technical conceptions and solutions. Therefore, rival proposals to the same policy problem are the raw material of the analysis.

\section{The decision-making process of the Bolsa Família program}

The decision-making process of PBF can be summarized in four stages, as shown in Table 01.

Table 01. Stages of decision-making in the Bolsa Família program

\begin{tabular}{ccccc}
\hline \multirow{4}{*}{ Period } & Stage 0 & Stage 01 & Stage 02 & Stage 03 \\
\hline Activities & Oct/Dec 2002 & Jan/Oct 2003 & Oct 2003/Jan 2004 & Jan 2004 \\
\cline { 2 - 4 } & Diagnosis & Formulation of & Interlude & New Arena on \\
& Work of the & PBF & & \\
& Sectorial & Chamber of Social & Group of Unification & Building MDS \\
& Transitional Team & Policy & & \\
& & & \\
& & & \\
& & Technical and & \\
& Working Group & \\
\hline
\end{tabular}

6 The article uses the real names of these stakeholders to demonstrate their hybrid positions and identification with different groups. All those interviewed authorized the use of their names. 
At its very beginning, the group in charge of formulating the PBF was split into two broad proposals. One group supported the unconditional basic income model advocated by Senator Eduardo Suplicy and Ana Fonseca7, among other scholars. A second model was created by the economist José Graziano and Maya Takagi ${ }^{8}$, whose proposal was to create a Food Card (Cartão Alimentação), considered as a first step to a broader food security program, including social control and local development (Trevisani et al., 2012, p. 504).

\section{Stage 0: the diagnosis of CCTs and its relations with social policies}

After the election in October 2002, the newly-elected president Luis Inácio Lula da Silva designated five sectorial transitional teams to build a diagnosis of the entire federal government (MONTEIRO, 2011, p. 44; VIEIRA, 2011, p. 38). For our study, the transitional teams of Social Policy and Economic Development are crucial, especially in three sectors: CCT programs, Food Security and Nutrition and Social Assistance.

The CCT sector, coordinated by Ana Fonseca, recommended the unification of all the existing CCTs into one program, based on arguments of economic efficiency. The Food Security and Nutrition sector expanded the diagnosis on poverty and food security and reintroduced the government plan elaborated for the 2002 presidential elections. This proposal launched the basis for the Zero Hunger Program (deemed the flagship program on social policy during Lula's election), which combined food security and family agriculture with social movements and civil society participation (TAKAGI, 2012). The reasoning behind its creation was that it is possible to eradicate hunger in the country with the adequate combination between emergency initiatives and coordinated articulation of structural actions, oriented for economic development and employment generation (TAKAGI, 2006, p. 02). The content of the Social Assistance sector's report is still not publicized, nor explored in the literature that

7 Ana Fonseca is an expert in programs regarding "minimal income". She worked as a government advisor on social issues for the Workers Party (PT) and she was the coordinator of the CCT programs in the Transitional Team of Social Policy in Stage 0 of the analysed period.

8 Maya Takagi is an expert in food security and supply. She worked in the Transitional Team of Economic Development, co-producing the Report on Food Security and Family Agriculture. Additionally, she worked as the head of Ministerial Advisors on the Special Ministry for Food Security and Fight against Hunger in 2003, as a Special Presidential Advisor from 2005-2010 and as Secretary in the National Food Security and Nutrition Secretary/MDS from 2011-2012. 
approaches the Transitional teams (COSTA E ANDRADE, 2003, pp. 17-19; VIEIRA, 2011, p. 34); thus, it will not be addressed here.

At the end of this process, the proposal of the Food Security and Nutrition sector gained more resonance in the initial strategies of government, which led to the creation of the Zero Hunger Program and a ministry responsible for its implementation, the Special Ministry for Food Security and Fight against Hunger (MESA). This act was the result of two main factors. First, President Lula's decision to prioritize policies against hunger, viewed as unacceptable in a country with food abundance (TAKAGI, 2006). Secondly, President Lula was a close friend of José Graziano, who came to be the Minister of MESA (FONSECA, 2012).

According to Fonseca (2012), the merger of the CCTs did not take place when Lula took office, because: Fonseca "proposed to take the cash transfer programs to the (MESA) minister. He does not agree with it, as he says his ministry was still starting its activities. He had a lot more power than me, a lot more. He sets up a new program [Food Card], which overlaps with something that was already in place [Bolsa Alimentação - Food Benefit]" (FONSECA, 2012). She repeated the criticism, but focused on technical arguments: "It sounded insane to have more than 16 million families on more than one cash transfer program. It has such a high cost, you have no idea about the costs of paying the same families more than once; and it was all operated by the bank! Each family was on 1.82 programs, which accounts for saving BRL R\$ 92 million in banking. Besides the existing different conditionalities" (FONSECA, 2012).

One may note a technical dimension in Fonseca's speech (2012), based on the notions of accountability and efficiency of gains by virtue of centralising the coordination of the programs. On the other hand, she also advanced a political argument, by stating her belief that Minister Graziano was very powerful, due to the leading role played by the Zero Hunger Program (and assigned by President Lula) in the social field. Only if the Zero Hunger Program lost its credibility or if the merging agenda gained more support and was backed up by other powerful politicians would this initial decision on policy design be reverted. This non-technical dimension reveals the political dimension in the speech of this high-level federal bureaucrat, and so, her hybrid behaviour as a policy-maker. 
The idea related to the unification of all the existing CCTs into one program did not generate immediate results, but remained in the political community agenda.

\section{Stage 01. The formulation of PBF}

This stage can be further split into three phases:

\section{The contradictory beginning of Lula's office}

President Lula created two new ministries, the Ministry of Social Assistance and Promotion (MAPS) and MESA, in January 2003. Both were directly bound to the presidency, which demonstrated the political priority of the matter. According to Provisional Measure № 103, from January 01, 2003, which was later passed as law on May 28, 2003 (Law № 10.683), MAPS was in charge of coordinating, articulating and evaluating the federal government's social programs. Conversely, MESA was in charge of formulating and coordinating the implementation of the National Policy on Food Security, which aimed at fighting hunger in the entire country.

However, establishing two new ministries to address very similar areas was against the recommendations of the reports from the Social Policy Transitional Team, which argued that institutional fragmentation and limited coordination of social policies were problems to be overcome by the new government. Such a decision by President Lula demonstrates that different technical-political groups were incorporated into the new government's structure, even if this did not seem to be the most rational path of action according to the transitional team in charge of framing the CCT, since it generated space for competition among groups, more particularly "competition of analysis" (LINDBLOM, 1980).

Social policy ambiguity and institutional fragmentation were indeed aggravated by the establishment of the new ministries and by the maintenance of the existing cash transfer programs. The sectorial ministries not only kept their programs (even enlarging program targets and benefits), but were also willing to create new programs, with the purpose of boosting their relative positioning within the federal government.

Despite the apparent lack of control, Lula's office established the Social Policy Chamber (CPS) in order to coordinate the development of social policies and avoid 
overlapping between the duties of ministries and secretariats ${ }^{9}$. The CPS has become the first locus of what Lindblom (1980) labeled as the "competition of analysis", under the coordination of the Minister Chief of Staff of the Presidency of the Republic, José Dirceu. Among the members of CPS, José Graziano, Minister of MESA; Benedita da Silva, Minister of MAPS10; Cristovam Buarque, Minister of Education, and Humberto Costa, Minister of Health, were key actors in this dispute around the formulation of new social programs.

The first CPS meeting, held in January 2003, aimed to evaluate Fernando Henrique Cardoso's government social policies and programs. It identified the deficits of the Single Registration (Cadastro Único) policy, the overlapping of programs, the fragmentation of actions and the waste of resources as the main problems affecting the programs at that time (MONTEIRO, 2011). Such observations were in line with the reports of the Social Policy Transitional Team, specifically its CCT Sector.

The Zero Hunger Program was officially launched on January 30, 2003. The launch received extensive coverage by the media and was a source of debate amongst society in general. The main criticisms to the program at its initial stage were the restrictions on the use of the Food Card (food vouchers) and the excessive bureaucratisation for controlling costs. Another controversial aspect of this policy was whether the new card would replace the existing cash transfer programs. According to MESA Minister José Graziano, the Food Card would replace the Ministry of Mine and Energy's (MME) gas vouchers and the Ministry of National Integration's (MIN) income vouchers, launched under FHC. All other social programs remained active within their sectorial ministries (MONTEIRO, 2011, pp. 63-64).

The second CPS meeting was held on February 14, 2003. In this meeting, Benedita da Silva stated that MAPS and the Ministry of Planning, Budget and Management (MP) were evaluating the social performance of each ministerial body involved in social policy. The outcomes of this evaluation would be presented in the next CPS meeting in March. They decided that another technical meeting coordinated by the Chief of Staff of the Presidency of the Republic, Minister José Dirceu, would be held at a

9 CPS was formally created by decree number 4714 on May 30, 2003. Available in: http://www.planalto.gov.br/ccivil_03/decreto/2003/D4714.htm.

10 During this phase, two groups composed the MAPS. The first was linked to the Executive Secretary, Ricardo Henriques, who proposed the unification of current CCTs. The second and major group was composed by social workers linked and represented by Minister Benedita da Silva. For this group, the main goal was the reinforced role of Social Assistance through the instruments of CadÚnico and spaces for family assistance. 
later date. Delegates of each social ministry would take part in the meeting to accelerate the evaluation of the programs.

The third CPS meeting was held on March 13, 2003, when several controversies were announced in the media. One instance involved Cristovam Buarque, Ministry of Education, who stated that his ministry would present an alternative plan to the Zero Hunger Program.

The disagreements and clashes between the different groups in charge of the federal government's social policies were evident. President Lula started the meeting by demonstrating his dissatisfaction towards the clashes and by affirming that Benedita da Silva should mediate the conflicts, since she was the head of the ministry in charge of the coordination of the federal government's social policies. Moreover, he set new rules for the game: he stressed the need for inter-ministerial coordination before starting or announcing measures. For the first time since elected, the president spoke about the urgency to unify social policies and to put MAPS in charge of evaluating such policies.

In this meeting, Benedita da Silva was due to present a diagnosis of the social performance of each sectorial ministry and the CPS program for 2003. However, Silva informed participants that the ministry was still gathering data on social policies from other ministerial bodies. She advocated for the establishment of a new initiative, the Program for Integral Aid to Families (PAIF), which consisted in organising and managing system of social aid activities, which would enable the implementation of the National Policy on Social Aid. According to Monteiro (2011), Benedita da Silva's presentation did not meet President Lula's expectations. He envisaged MAPS to be in charge of coordinating the federal government's social policies. Instead, she showed a strategy that was limited to the field of social aid.

Therefore, Lula's dual strategy for tackling poverty and hunger with MAPS and MESA would have to be reviewed. According to Lula, Minister da Silva's proposal was insufficient to coordinate the social and CCT policies that already existed, and he pointed to the need to develop a unified social policy that could be easily communicated to society (MONTEIRO, 2011, p. 67).

Following all ministers' interventions, the MAPS Executive Secretary, Ricardo Henriques $^{11}$, made an intervention that surprisingly opposed that of Minister Benedita 
da Silva. He pointed out to the critical lack of focus in Brazilian social policies, regarding both formulation and implementation. He highlighted the following dimensions of social policies disintegration: uncertainty and overlapping of competences in the coordination efforts among the federal agencies, complementarity of some policies and programs, the possibility of identifying and consolidating areas of convergence and integration between CCTs, and the need to understand poverty as a multi-dimensional problem in need of individual solutions to the needs of each family. Henrique's explanation implicitly quoted the guidelines of the CCT Sector's report on the Social Policy Transitional Team.

By the end of the meeting, Lula determined, against all expectations, that the Chief of Staff of the Presidency of the Republic, Minister José Dirceu, should continue to coordinate CPS, and advocated for the establishment of a Technical Group to carry out a study on social policies in Brazil. Ricardo Henriques, MAPS Executive Secretary, and Miriam Belchior, Special Adviser to the Presidency of the Republic, as well as the Office of the Chief of Staff (Casa Civil) and the Ministry of Planning, Budget and Management would participate in this group.

This new presidential guideline modified the initially-designed strategy, as it kept the MAPS Minister away from the coordination of social policies. Thus, as two broad proposals were already at stake, namely the Food Security Program and unification of CCTs, the suggestion of a third proposal (PAIF) was rapidly ruled out, which meant a loss of power to the MAPS minister as a side effect.

\section{Building the decision on the merging of cash transfer programs}

During the fourth CPS meeting on April 02, 2003, the Technical Group that was established in the previous meeting presented the results of the survey on social policies in Brazil. Ricardo Henriques stated that the group aimed to examine the overlap and fragmentation of Brazilian social policy in a broader sense, rather than restricting the scope of the survey to social aid programs. The group pointed out the main challenges to

and future Minister from the Workers Party (PT), Benedita da Silva. Despite this connection to the PT, he contributed to the proposals to the 2002 presidential elections of parties not aligned with PT, in particular the CCTs' merger. Such proposal was transmitted to the coordinator of the transition team, Antônio Palocci, by Armínio Fraga, who was linked to FHC government. Thus, Henrique's proposal to CCTs was already known in the Ministry of Finance and MAPS (CARIELLO, 2012; HENRIQUES, 2015). 
social policies, such as lack of targeting, adequacy, efficiency and efficacy of interventions. They made several proposals, such as the merging of processes for registering benefit-holders, designing a single card for integrating cash transfer programs, incorporating "exit door" strategies, creating program conditions that the beneficiary families had to comply with and decentralised execution (MONTEIRO, 2011).

President Lula appreciated the group's presentation, and stated that the results shown were consensual (MONTEIRO, 2011). He also asserted that "the federal government would run only one program" and that each ministry would no longer have "their own poor people to take care of" (MONTEIRO, 2011, p. 71). At that particular moment, Lula clearly demonstrated his intention to merge the CCTs, even though it was not clear how the program would be structured, nor which ministry would lead it. The president decided that an alternative to the existing problematic social policies should be found whilst keeping the existing programs running, since "one should not change the flat tire of a car if they do not have a spare wheel" (MONTEIRO, 2011, p. 71).

The competition of analysis between the high-level federal bureaucracy of ministries engaged with social programs (particularly the Ministries of Education, Health, MAPS and MESA) was intensified due to the uncertainty that was created by the decision to merger the CCTs. Apart from the Ministry of Education (MEC), all other ministries had numerous observations of and reservations to Ricardo Henrique's proposal. They have also highlighted the positive aspects of their own performance and proposals.

For instance, Humberto Costa, Ministry of Health (MS), stressed that health policies involved important conceptual issues that were specific to that field. He proposed a change in the language of the text, since, according to him, the word "targeting" was too linked to the neoliberal vocabulary. Conversely, Benedita da Silva admitted that a reform in the country's social policy was much needed, but stated that such reform should be made in a different fashion. José Graziano criticised the Technical Group's definition of poverty, which was exclusively based on financial criteria.

Finally, President Lula closed the meeting by determining that the Technical Group should be expanded. Such expansion would encompass the sectorial ministries (Ministério da Educação e Cultura, Ministério da Saúde, MESA, Ministério de Minas e Energia and Ministério da Integração Nacional/ Ministry of Education, Ministry of Health, Special Ministry for Food Security and Fight against Hunger, Ministry of Mine 
and Energy and Ministry of National Integration.). He also requested the presentation of a strategy and a timeframe for implementing the proposals during the following CPS meeting.

In that same month, on April 16, a new move by MESA challenged the decision made by President Lula earlier that month, shedding light on the disagreements and contradictions that were not explicit in the previous CPS meeting. On that day, Minister Graziano held a side meeting at his office, without the participation of the Chief of Staff of the Presidency of the Republic, Ministry of Social Security and Welfare, and the Advisory Board to the Presidency of the Republic. The purpose of this meeting was to establish a new body, the Zero Hunger Program Chamber, to monitor the Food Card Program and to turn it into a crosscutting program. In this meeting, MESA proposed two separate initiatives to the integration of cash transfer programs, as opposed to the merger of the programs advocated by the Technical Group. In conclusion, following MESA's disagreement on the CPS's decision, MESA sought to reinforce the technical validity of Graziano's analysis and to gather political support for it. Thus, as stated by Lindblom (1980), the technical dispute was complemented by the political one.

Concomitantly, in the sectorial meetings booked on April 03, the CPS meeting started with Ministério da Educação e Cultura on April 28. In this meeting, Ricardo Henriques presented a summary of the study on the social policy of Brazil and stressed the relevance of the conditionalities to unify the CCTs and decentralise management. Also, he noted that the income transfer programs did not need to be linked to their respective sectorial ministry, since such ministries would be in charge of checking if the program eligibility requirements were being met and on the quality of the services being delivered. Conversely, Cristovam Buarque made some observations to the Technical Group's proposal. He said that it was necessary to know each program better (its conditions and particularities) prior to defining a final management proposal. $\mathrm{He}$ stressed the importance of getting the funding and capacity for adequate delivery of services, and, consequently, to ensure that the eligibility requirements are being met.

The sectorial meeting with MESA was held on May 07. In this meeting, José Graziano stated that the discussion held by the Technical Group only referred to cash transfer initiatives and did not address the government's social policy, which he believed to be much broader. He also stressed that the Food Card Program (Cartão Alimentação in MESA) and Food Benefit (Bolsa Alimentação in Ministry of Health) could 
be merged easily; their respective ministries were already discussing this possibility. He noticed that it would be difficult to merge such initiatives with the School Benefit (Bolsa Escola), since it had different eligibility criteria and timing. Further, he explained that there was consensus regarding some of the aspects of the proposal to merge the social policies, such as the single registration, minimum allowance, requirements to be linked to the family profile. However, he pointed that there was no consensus regarding how the new program would be carried out or managed.

In the sectorial meeting with the Ministry of Health on May 13, Minister Humberto Silva talked about the need to understand the cash transfer policy differently from other social policies: while the first needs targeting, the latter must be universal and apply to all citizens. He expressed concern on health community agents being assigned to multiple roles.

Thus, sectorial ministries, in particular the MESA, acted rationally towards developing a strategy to keep their prominent role in the social field. They seemed to have accepted the merging proposal that was debated in the April 03 CPS meeting (although still supporting their criticisms and observations of the proposal). Concomitantly, their strategy included unexpected initiatives on the integration of cash transfer programs that were not initially under their responsibility. In sum, it may be said that despite the recommendations made by the CPS Technical Group to merge and advance the cash transfer programs, the four ministries in charge of cash transfer programs were still acting in an independent fashion, not in clustered coordination with the other ministries. Instead, they advanced technical arguments to support their aim of having a leading role on the Lula's government's highly-visible social policy.

A detailed preliminary proposal emerged between the months of April and June, when the Technical Group met with the sectorial ministries. As a result, several improvements to the merging of cash transfer programs were made. Moreover, the proposal suggested creating a specific Working Group (WG) to formulate the new program in details. The group had representatives from the sectorial ministries (MAPS, MESA, MME, MEC and MS), the office of the Chief of Staff of the Presidency of the Republic, the Ministry of Planning, Budget and Management, the Ministry of Finance (MF), IPEA ${ }^{12}$, CAIXA $^{13}$ and the Special Advisory Board to the Presidency (AESP).

12 IPEA is the acronym for the Institute of Applied Economic Research, a federal research foundation linked to the Secretary of Strategic Issues of the Presidency of Brazil. Its research 
The fifth CPS meeting was scheduled for June 12, after all sectorial meetings were finished. Two new controversial elements emerged days before the meeting, which led to a certain degree of unrest in the political environment. First, Minister Cristovam Buarque unexpectedly proposed four new cash transfer programs in a statement to the media. Secondly, MESA presented an alternative project for merging the cash transfer programs. At this point, the competition between the ministries' projects was intensified. It reveals that the tension between the CPS and the sectorial ministries was permanent and relevant, since each ministry apparently agreed with the new directives, but was also launching its own programs, making proposals and recommendations contrary to the ones agreed in CPS meetings, with the aim of keeping or enhancing their role in implementing one of the most prominent programs of Lula's government.

With these events having taken place before the fifth CPS meeting, the Technical Group aimed to build a consensus on a sole proposal for centralising cash transfer programs amongst the ministries participating in the CPS. MESA's proposal and the launching of MEC's new programs surprised the Technical Group. However, the ministries' negative reaction towards the termination/merging of their programs should not be surprising, since both individuals and organisations tend to design rational (limited) strategies to keep their programs, responsibilities and power, as argued by Crozier (1964) and Lindblom (1980).

Even though such institutions realized that the merging of cash transfer policies could make these initiatives more rational and efficient, they did not agree with it, which confirms that the actions undertaken by each ministry were based on their own rational calculations and limited analyses. Since the Technical Group's proposal would no longer set food security (and the Zero Hunger Program) as a priority in the government agenda, MESA had one additional reason to oppose to the Technical Group's proposal.

Consequently, Takagi (2012), a policy-maker working at MESA, evaluated the merger of the CCTs based on the impacts it would have on the Zero Hunger Programme:

The MESA agreed with the initiative (merging the CCT). It thought the merger would bring more rationality into play. On the other hand, it thought it would massively change the strategy for implementing the Zero

activities provide institutional and technical support to government's actions related to the formulation of public policies and development programs.

13 CAIXA stands for Caixa Econômica Federal, a public bank that is responsible for the operationalization of important national social programs, such as Bolsa Família. 
Hunger Programme, since the key action taken in the first year (the Food Card

- entry door to various other initiatives) would not be under the supervision of the Ministry anymore. But the Zero Hunger Programme was a lot broader than the Food Card (TAKAGI, 2012).

In other words, Takagi (2012) did not criticise clearly and technically the merger, as she agreed that it would make the program more rational. However, she made use of political claims to argue that such a decision was based on lack of knowledge of the Zero Hunger Program, for the Food Card was only one of its elements, although of pivotal importance.

The controversy among the ministries was solved by President Lula. He decided that the Working Group should proceed with the final proposal for integration of the cash transfer programs. The final proposal should be discussed with and agreed by other levels of government, particularly governors. This meeting was a landmark to the decision of merging the CCTs, as the discussion on MESA's and Working Group's opposing proposals came to an end.

Hence, it is clear that different groups made use of technical and political tools to achieve their goals. The MAPS Executive Secretariat made use of technical knowledge to leverage its proposal and promote the merger of the CCTs, on the grounds that such an outcome would facilitate the management of the policies to fight poverty. This demonstrates that MAPS had, at the same time, institutional and diffuse/selfless goals, which is also true for the MESA. However, one must draw a line between the MESA's and the MAPS' strategies; the proximity to and the relation based on trust that they have built with the president paradoxically gave more power to Minister Graziano, but these initial advantages seem to have undermined MESA's insertion in the games of power. MESA only sought for political support and showed more flexibility towards its own proposal when there was no way back from the merger.

\section{Formulating the Bolsa Família Program}

The Working Group with experts from several government bodies was established in the June 12 meeting. It was in charge of consolidating a final merging proposal for the CCTs by July 28. To this end, the group was divided into four subgroups, with different responsibilities:

- Technical Group: program design and the strategy for its implementation;

- Registry Group: operational and technological elements of registration; 
- Legislation Group: analysis of the legal framework of ongoing programs and advancing legal suggestions to the merging process;

- Budget Group: budget allocation.

By the end of such period, meetings were held to present the proposal to the president, ministers and representatives of the government bodies involved in the Working Group and of the Ministry of Finance, Ministry of Mine and Energy, Communication Department, and Caixa Econômica Federal. Although there were still controversies regarding the Working Group's proposal, they were no longer related to the structure of the proposal or guidelines to the merging process, which suggests that the previous controversy between MESA and the Working Group was not so latent anymore.

Several technical meetings were held in August, and on August 27 the final version of the CCT merging proposal was finalised. Highlights of the proposal are the merger of benefits and eligibility criteria (both prior to and to keep receiving the benefit), community participation, social control, and inter-government coordination for the program's implementation. The official statement on the design of the new program would be made in September. Between August 2003 and September 2003, the proposed program would be publicised and consultations on the final draft of the program would be evaluated by federal entities and civil society.

Finally, the Working Group finished its project in October 2003. Four of the existing federal government cash transfer programs were merged (School Benefit, Food Benefit, Gas Benefit and Food Card). The new Cash Transfer Program, the Bolsa Família Program, was launched on October 20 and established by the Law № 10.836. After months of dispute among different ministries, President Lula decided to change his initial decision and to alter the priority of his government's social policies from the Zero Hunger Program to the merger of the existing CCTs programs. At this point, President Lula decided to extinguish MESA and MAPS, and create a small group of high-level federal bureaucracy with the responsibility of managing the first initiatives of the newly created PBF.

\section{Stage 02. Interlude: the unification group}

From October 2003 to December 2003, there was an interlude period in the formulation of the PBF. After months of dispute, the presidency chose a small group of 
high-level federal bureaucrats to conduct the unification of CCTs, working directly with the presidency ${ }^{14}$. This choice reflects the president's preference to work with a single group, instead of allowing different groups to dispute for influence in the political decision-making process. This stage was also marked by Ana Fonseca's return to the game of power, since she was invited to coordinate the work of this new team.

Even though the president had already ratified the general structure of PBF, there were still decisions to make regarding the details of the new program. The unification group was then empowered by the presidency to occupy spaces for negotiation with different governmental and international organizations. According to Fonseca (2012), the unification group was responsible for conducting the negotiations with governors to commit fiscal resources to the program and with MEC and MS to define the conditionality involving these institutions. Similarly, in an interview, Cohn (2014) gives evidence of negotiation with international organizations:

It was very difficult to convince the World Bank representatives on the role of conditionalities (...). The World Bank proposals involved loans of a huge amount of money to assess and monitor the targeting (...) We worked hard to convince them on the understanding of conditionalities (...) Conditionalities were not for families; instead we intended to monitor the public policies implemented by the states, municipalities and the federal government. Our goal was not to take families out of PBF. Instead, as policy-makers find out that children are not attending school, we aimed that that municipalities would find out the reasons behind this absence. For us, condionalities have never been meant targeting! (COHN, 2014, p. ).

By the end of December, the unification group managed to merge the register of beneficiaries in the previous CCT programs into one single database, Cadastro Único, and to finalize an agreement with subnational governments regarding the implementation of PBF, although this negotiated partnership did not generate the expected results at the time.

\section{Stage 03. New arena on dispute: the creation of MDS}

In January 2004, the Bolsa Família Program was allocated to the newlyestablished Ministry of Social Development and Fight against Hunger (MDS), which

\footnotetext{
${ }^{14}$ Ana Fonseca, Claudio Roquete, Amélia Cohn, Valdomiro Sousa and André Teixeira formed this small unification group (COHN, 2014).
} 
reintroduced the high-level federal bureaucracy linked with MESA and MAPS, as well as the unification group.

In the early stages of MDS, members of the political groups present in the CPS were absorbed in its organizational structure. The unification group controlled part of the ministry: Ana Fonseca became the Executive Secretary and André Teixeira was nominated the National Secretary of Citizen Income (SENARC). This group was responsible for Cadastro Único and the management of the financial resources of PBF. The political community involved with MESA took over the National Food Security and Nutrition Secretary (SESAN). The group previously linked with Benedita da Silva and the Social Work agenda was incorporated into the National Secretary of Social Assistance (SNAS). The differences in the composition of these secretaries was analyzed by Dulci (2010, p 231), who shows that SENARC's staff was composed of a technical work force committed with social issues and PBF: this secretary offered courses and trainings in order to generate bureaucrats' identification with the program (SILVA, 2013, p. 92). On the other hand, SNAS was a department formed by social assistants and social scientists, with an active and historical political role in the struggle of social rights.

According to Takagi (2006), the fusion of these three organizations into one new [m]inistry, only two months later, was the probable and 'natural' upshot of all this institutional jugglery. However, its consequences, not all of them thought out deliberately, were deeper than the exchange of [three] [m]inisters in the social area (education, food security and social assistance) (TAKAGI, 2006, p. 161).

This author cites some of the aforementioned consequences, such as the redefinition of the Zero Hunger initiative from a program to a strategy that articulates a set of governmental actions in all spheres of the federation. Another consequence is a conceptual change involving the Mesa Program and the PBF. While the first was a programme concerning access to food, composed of different lines of action, the second was a cash-transfer programme aiming at providing minimal income along with conditionality.

Similarly, Aranha (2015) ${ }^{15}$ agrees that the creation of MDS provoked a broader change in the Zero Hunger initiatives: while in 2003 it was a concrete policy, from 2004

15 Adriana Aranha is a social worker with local government experience in food security and nutrition, public policies and Zero Hunger. She was the Special Advisor and Chief of Staff of MDS from 2004-2010.

(2016) $10(3) \quad$ - $\quad$ e0008-21/26


on the fight against hunger became a more abstract ideal to social policies, producing some identification among the different political communities.

Patrus Ananias became the first Minister of MDS in 2004. Affiliated to PT, Ananias was renowned for his work in social assistance and food security in the municipality of Belo Horizonte in the state of Minas Gerais. Because of his experience and conciliatory behavior (ARANHA, 2015), he managed to coordinate this ministry during Lula's entire term, keeping the political groups' disputes under control and letting them consolidate policies and offices they deemed as important.

Consequently, the creation of MDS restored the game of power among these groups, but since there was a clear hierarchical structure, with a minister in a higher position than the secretaries, the degree of these conflicts diminished. For instance, Silva (2013) showed that the conflicts remained active in the MDS routines, especially in actions that demanded the internal coordination of middle-level federal bureaucracy. In Silva's interviews, MDS's staff told him it was easier to cooperate with external bureaucrats than with MDS' secretariats.

One characteristic of MDS that makes it different from the other ministries is the large number of "Public Managers"16 occupying different positions in the institution, especially in SENARC. According to Silva (2013) and Aranha (2015), it is possible to understand this recruitment as a strategy to strengthen the MDS administrative capacity. Although they did not have previous involvement with the proposal of the fight against poverty, the ministry managed to engage the "Public Managers" emotionally with this theme.

Kadri (2012) ${ }^{17}$ reinforces this interpretation:

Firstly, a very personal view... it might be strong, but working with the Bolsa Família Program is passionate. It is a wonderful feeling... Today's meeting may impact the lives of a quarter of the Brazilian population

16 The federal government has a consolidated civil service career called "Expert in Public Policies and Government Management". They are commonly referred to as "Public Managers". Because of their high-level skills-they are recruited through a meritocratic and competitive selective process, must attend preparation courses, etc.-they are frequently recruited to high-level federal bureaucracy positions.

${ }^{17}$ Nabil Kadri held a DAS position at the MDS, where he was responsible for improving the Single Registration (CadastroÚnico). He also worked for the Secretariat for Social Development of the State of São Paulo, in the social department of the National Bank on Socio-Economic Development (BNDES) and was back to the MDS during the first term of President Rousseff's government. 
tomorrow and produce day-to-day outcomes, which are acknowledged by the IDB, World Bank or Brazilian researchers. Concrete outcomes in people's lives with academic results as well (KADRI, 2012).

Kadri's statement (2012), as well as other interviewees', reflected their deep involvement with their field of work. Two of them have specifically used words derived from the word "passion", whilst one has described their involvement as being moderate. The word "passion" (and related words) means deep emotional involvement, which is unknown to the ethos of the classical definition of bureaucracy. Thus, this attitude is completely opposed to the obedience to formal rules that classically defined the bureaucrats, and it approaches the field of politics, which facilitates innovation. Consequently, it illustrates the possibility of politicization of the bureaucracy, as argued by Aberbach, Putnam and Rockman (1981).

On the other hand, the idea of "passion" among high-level federal bureaucracy also helps to explain the defensive attitude towards change. The sum of technical content with emotional and political involvement supports the existence of more reactive behavior when faced by alternative proposals.

\section{Conclusion}

This case study confirms that policy-makers, be they appointed ones or bureaucrats, organize themselves around different technical and political projects, acting to leverage their influence on the decision-making process.

The PBF decision-making process was marked by conflict, tensions and nonlinearity. Such conflicts entailed games of power and competition of analysis, as stated by Lindblom (1980), the fight of ministries and their federal high-level advisers strategies to resist the creation of a new program being the clearest evidence. Groups within the policy community in charge of formulating President Lula's social policy designed rational strategies in a context of limited rationality to maintain or improve their influence. That is to say, given the possibility of losing space, resources and responsibilities attached to social programs, they organized themselves to leverage their own authority, on the grounds of efficacy reasons.

The political defense of projects was grounded on technical arguments, so as to demonstrate the superiority of each own proposal along with the weaknesses of rival ones. This pattern was observed initially in the Working Group with the use of technical 
arguments to get support inside the presidential cabinet, and, after the decision to merge the CCTs, with the exposition of technical arguments and projects to the press as a last resort.

Groups' resistance and competition were solved by a visible actor, President Lula, when creating the small Working Group, who eventually achieved the presidential aspiration of merging cash transfer programs into one body. As a result, all sectorial ministries lose, since they would no longer be able to design and implement CCTs.

Of course, only more studies-extended to other policies and cases-will give support to the conclusions reached in this case study. However, our conclusions can act as reference points for future studies that will contribute to the knowledge of decisionmaking processes in social policies.

Revised by Lindsey Silva Submitted on March 07, 2015 Accepted on January 16, 2016

\section{References}

ABERBACH, Joel D.; PUTNAM, Robert D. and ROCKMAN, Bert A. (1981), Bureaucrats and politicians in western democracies. Cambridge: Harvard University Press. 322pp.

ARANHA, Adriana (2015), Interview with Fernanda Lima e Silva and Fabio Pereira de Andrade. São Paulo: September 23, 2015.

BONIS, Daniel De; PACHECO, Regina Silvia (2010), Nem político, nem burocratas: o debate sobre o dirigente público. In: Burocracia e política no Brasil: desafios para o Estado democrático no século XXI, Edited by ABRUCIO, Fernando Luiz; LOUREIRO, Maria Rita e PACHECO, Regina Silvia. Rio de Janeiro: Editora FGV. pp. 329-362.

CARIELLO, Rafael (2012), 0 liberal contra a miséria. Revista Piauí. Edition 74. pp. 02-25.

COHN, Amélia (2014), Interview with Fabio Pereira de Andrade. São Paulo: 19 May 2014.

COSTA, Nilson do Rosário (2009), A proteção social no Brasil: universalismo e focalização nos governos Lula e FHC. Ciência \& Saúde Coletiva. Vol. 14, № 03, pp. 693-706.

COSTA, Cátia C., ANDRADE, Helenice (2003), Governo de transição FHC-LULA: constituição, funcionamento e resultados dos trabalhos realizados pela equipe de governo de transição FHC-LULA. Documento de Trabalho № 10. Série Estudos de Políticas Públicas. Rio de Janeiro: Observatório Universitário. 
CROZIER, Michel (1964), The bureaucratic phenomenon. Chicago: The University of Chicago Press. 318pp.

D’ARAÚJO, Maria Celina (2009), Elite dirigente do governo Lula. Rio de Janeiro: Fundação Getúlio Vargas - CPDOC. 140pp.

DULCI, Otávio Soares (2010), Avaliação de programas sociais: desafios e potenciais na construção de um sistema de informações. In: Ministério do Desenvolvimento Social e Combate à Fome. Cadernos de Estudos Desenvolvimento Social em Debate. № 13. pp. 221-237.

FONSECA, Ana (2012), Interview with Fernanda Lima e Silva and Fabio Pereira de Andrade. São Paulo: November 09, 2012.

HAAS, Peter M. (1992), Introduction: Epistemic Communities and International Policy Coordination. International Organization. Vol. 46, $\mathrm{N}^{\circ}$ 01, pp. 01-35.

HALL, Anthony (2006), From Fome Zero to Bolsa Família: social policies and poverty alleviation under Lula. Journal of Latin American Studies. Vol. 38, № 04, pp. 689-709.

HENRIQUES, Ricardo (2014), Interview with Fabio Pereira de Andrade. São Paulo: December 10, 2014.

KADRI, Nabil (2012), Interview with Fernanda Lima e Silva and Fabio Pereira de Andrade. São Paulo: November 06, 2012.

KINGDON, John W. (1995), Agendas, alternatives and public policies. New York: HarperCollins College Publishers. 254pp.

LINDBLOM, Charles E. (1980), O processo de decisão política. Brasília:. Editora Unb. 124pp.

LÓPES-ARANGUREN, Eduardo (2000), El analisis de contenido tradicional. In: El analisis de la realidade social: métodos y técnicas de investigación. Edited by FERRANDO, Manuel Garcia, IBÁÑES, Jesús, and ALVIRA, Francisco. Madri: Alianza Editorial. pp. 270-305.

LOUREIRO, Maria Rita; ABRUCIO, Fernando Luiz (1999), Política e burocracia no presidencialismo brasileiro: o papel do Ministério da Fazenda no primeiro Governo Fernando Henrique Cardoso. Revista Brasileira de Ciências Sociais. Vol. 14, № 14, pp. 69-89.

MONTEIRO, Iraneth Rodrigues (2011), Integração de políticas sociais: um estudo de caso sobre o Bolsa Família. Masters dissertation. Centro de Pesquisa e Documentação de História Contemporânea do Brasil (CPDOC). Rio de Janeiro: Fundação Getúlio Vargas.

OLSEN, Johan P. (2005), Maybe it is time to rediscover bureaucracy. Journal of Public Administration Research and Theory. Vol. 64, pp. 16-24. 
PACHECO, Regina S.V.M. (2002), Política de Recursos Humanos para a Reforma Gerencial: Realizações do Período 1995-2002. Revista do Serviço Público, Vol. 53, № 4, pp. 35-53.

RHODES, R.A.W. (2006), Policy Networks. In: MORAN, Michael; REIN, Martin; GOODIN, Robert E. The Oxford Handbook of Public Policy. Oxford. Oxford University Press, pp. 425-447.

SELZNICK, Philip (1943), An approach to a theory of bureaucracy. American Sociological Review. Vol. 08, № 01, pp. 47-54.

SENNA, Mônica de Castro Maia; BURLANDY, Luciene; MONNERAT, Giselle Lavinas; SCHOTZ, Vanessa, and MAGALHÃES, Rosana (2007), Programa Bolsa Família: nova institucionalidade no campo da política social brasileira? Revista Katálysis. Vol.10, № 01, pp. 86-94.

SILVA, Lucas Ambrózio Lopes da (2013), A construção federal da intersetorialidade na política de desenvolvimento social brasileira: o caso do programa Bolsa Família. Masters dissertation. Universidade Federal de São Carlos, Centro de Educação em Ciências Humanas, Programa de Pós-Graduação em Ciência Política. São Paulo.

SILVA, Maria Ozanira da Silva e; YASBEK, Maria Carmelita; GIOVANNI, Geraldo di (2007), A política social brasileira no século XXI: a prevalência dos programas de transferência de renda. São Paulo: Cortez Editora. 225pp.

TAKAGI, Maya (2006), A implantação da política de segurança alimentar e nutricional no Brasil: seus limites e desafios. Doctoral Thesis. Instituto de Economia, Universidade Estadual de Campinas. São Paulo.

TAKAGI, Maya (2012), Interview with Fernanda Lima e Silva e Fabio Pereira de Andrade. São Paulo: December 13, 2012.

TREVISANI, Jorginete de Jesus Damião; BURLANDY, Luciene, and JAIME, Patrícia Constante (2012), Fluxos decisórios na formulação das condicionalidades de saúde do Programa Bolsa-Família. Saúde Social. Vol. 21, № 02, pp. 492-509.

VIEIRA, Ana Maria Machado (2011), Multiestratégia de implementação do Programa Bolsa Família e do Cadastro Único no período 2005 a 2007. Masters dissertation. Fundação Oswaldo Cruz. FIOCRUZ. Rio de Janeiro.

WEBER, Max (1993), Parlamento e governo numa Alemanha reordenada: crítica política da burocracia e da natureza dos partidos. Petrópolis: Editora Vozes. 174pp.

WILSON, Woodrow (2005), 0 estudo da Administração. Revista do Serviço Público. Vol. 56 , № 03 , pp. 349-366. 